\title{
Study the effect of Heavy Oil Fuel Ash on the geotechnical properties of clay soil
}

\author{
R. Ousta ${ }^{1}$, A. Tawalo ${ }^{2, *}$ \\ ${ }^{1}$ Tishreen University, Department of Geotechnical Engineering \\ AL-Thowra Street, GRF4+3W Latakia, Syria \\ ${ }^{2}$ Széchenyi István University, Department of Structural and Geotechnical \\ Engineering, Egyetem tér 1,H-9026 Győr, Hungary \\ *e-mail: aliibrahimtayalo@tishreen.edu.sy
}

Submitted: 21/03/2021; Accepted: 19/04/2021; Published online: 22/04/2021

Abstract: Power stations are widely spread in Arabic Syrian Republic, unlike most of power stations in the world that work by using coal as the operating fuel, most of Syrian power stations depend on the heavy fuel oil to generate electricity. Although there are a lot of studies about use of the fly ash produced from burning coal, the fly ash resulted by using heavy fuel oil as an operating material for the power stations had less attention. This paper aims to study the effect of this type of fly ash on the geotechnical properties of the clay soil and comparison it with the effect of fly ash resulted by power stations that use the coal. Two percentages of heavy oil fuel ash were mixed with the soil $5 \%$ and $10 \%$ of the dry soil weight with two curing periods 7 and 28 days. The results indicated that adding heavy oil fuel ash to the soil will decrease the cohesion in addition to increase the internal friction angle. There is not clear effect of the curing periods and the increase in the percentage of fly ash on the Atterberg limits.

Keywords: Fly ash, Clay soil, Geotechnical properties, Heavy oil fuel ash

\section{Introduction}

The Industrial Revolution made the things that we wouldn't expect to happen necessary things that we cannot imagine our life without them today. As is well known, every matter has advantages and disadvantages. The industrial revolution 
that was blessed by human at the beginning of the last century did not only bring benefit, but also the harm, as factory waste pollutes water, air and soil.

We can define soil pollution by saying: it is entrance of strange materials in the soil or an increase in the density of one of its natural components, which lead to a change in its chemical or physical properties or both, and these materials are called soil pollutants and may be pesticides, chemical fertilizers, acid rain or waste (industrial, household, radioactive, etc.) and others.

Power stations are widely spread in Syria and they are considered the main source of the electric power. Although most of countries use coal as the employed fuel of the power stations [1], most of Syrian power stations depend on the heavy fuel oil to generate the electric power.

Burning of coal and heavy fuel oil will produce fly and bottom ash. fly ash that caused by use coal in power stations is different from that caused by use heavy oil fuel.

Most of the research that studied the effect of fly ash on soils used the fly ash that caused by burning coal (Fig. 1). Erdal Cocka [2] studied the effect of fly ash produced from burning of coal on expansive soil and added it to the soil at percentages from $0 \%$ to $25 \%$ of the dry soil weight and two curing periods $(7,28)$ days, after that the mixtures were subjected to the free and oedometeric swell tests and their experimental results confirmed that the plastic index and the possibility of swell decreased with increase the percentage of fly ash and curing period. The optimum fly ash percentage for reducing swelling potential is $20 \%$ of dry soil weight.

Pandian et.al [3] studied two types of fly ash produced from burning coal, Raichur fly ash (Class F) and Neyveli Fly Ash (Class C) on the CBR properties of BC soil (Black Cotton Soil). The percentage of fly ash ranged from 0 to $100 \%$ of dry soil weight and the addition of fly ash to BC soil increased the CBR of the mixture (soil + ash) to the first optimum level. Further addition of fly ash more than the first optimum percentage caused a decrease in the CBR of the mixture by $60 \%$ and then the second optimum level.

Phanikumar and Sharma [4] conducted the same study on the effect of fly ash produced from burning coal on the geotechnical properties of the expansive soil by an experimental program. They studied the effect of fly ash on some parameters such as free swell, swell pressure, plastic index, and unconfined compressive strength. Fly ash was added at percentages $0,5,10,15,20$ of the dry soil weight and they concluded. 
- Increase percentage of fly ash reduced the plastic index and led to a decrease the free swell by $50 \%$ at $20 \%$ of fly ash.

- Increase percentage of fly ash also led to a decrease the optimum moisture content value (OMC) and an increase the maximum dry density $\left(\rho_{\max }\right)$.

- The undrained shear resistance (Su) increases with increase percentage of fly ash mixed with the expansive soil.
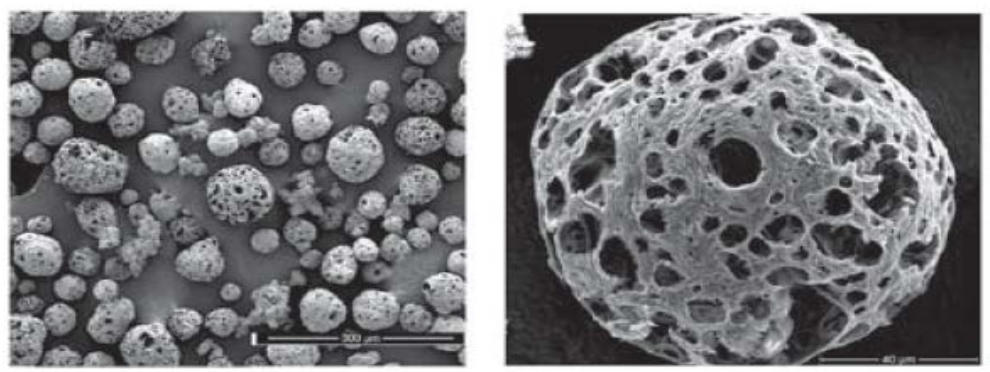

Figure 1. Carbon particle in heavy oil fuel ash [2]

Camilleri et al [7] used heavy oil fuel ash with Flowable Fill Concrete and with Hollow Masonry Units, and they concluded that the use of this type of ash with replacement percentages of the cement equal to $30 \%$ and $20 \%$, respectively is recommended.

The aim of this paper is to study the effect of Heavy Oil Fuel Ash (fly ash caused by burning heavy fuel oil) on the geotechnical properties of clay soil, where the power stations in Arabic Syrian Republic produce large quantities of this type of fly ash. So, it is important to know the effect of it on the clay soils and the possibility to find useful utilization in the field of geotechnical engineering and soil stabilization like fly ash produced by burning coal.

\section{Methods and materials}

This research depends on the comparative experimental approach and carried out by following these phases.

(a) Study the geotechnical properties of the natural soil.

(b) Study the geotechnical properties of the mixtures (soil + HOFA "Heavy Oil Fuel Ash"): the soil was mixed with two different percentages of heavy oil fuel ash (5 and 10) \% of the dry soil weight and the mixtures were tested for two curing periods (7 and 28) days. 
(c) Compare and discuss the results.

\subsection{The laboratory work}

The following tests were carried out on the natural soil:

- $\quad$ specific gravity (ASTM D854-98),

- $\quad$ standard Proctor test (ASTM D 698-91),

- Unconfined Compressive Strength (ASTM D2166-98a),

- Direct Shear Test for Soils Under Consolidated Drained Conditions (ASTM D3080-98),

- $\quad$ Sieve Grain Size Analysis (ASTM D4318-98),

- Atterberg limits (ASTM D4318-98),

- free Swell (ASTM D4546-98).

For the mixture (soil + HOFA), the samples were formed with the same density of the natural soil and the following tests were carried out.

- Unconfined Compressive Strength (ASTM D2166-98a).

- Direct Shear Test for Soils Under Consolidated Drained Conditions (ASTM D3080-98).

- Atterberg limits (ASTM D4318-98).

Free swell (ASTM D4546-98). (it was carried out for the mixture after 7 days of curing) results of laboratory work were combined in Table 1. 
Table 1. Geotechnical properties of the natural soil and the mixtures (soil + HOFA) for both curing periods.

\begin{tabular}{|c|c|c|c|c|c|}
\hline Parameter & Soil & $\begin{array}{c}5 \% \\
7 \text { days }\end{array}$ & $\begin{array}{c}5 \% \\
28 \text { days }\end{array}$ & $\begin{array}{c}10 \% \\
7 \text { days }\end{array}$ & $\begin{array}{c}10 \% \\
28 \text { days }\end{array}$ \\
\hline$G_{S}$ & 2.79 & & & & \\
\hline$\rho_{\text {max }}\left[\mathrm{kg} / \mathrm{m}^{3}\right]$ & 14.8 & & & & \\
\hline$\omega_{\text {opt }}[\%]$ & 29.4 & & & & \\
\hline $\begin{array}{c}\text { Percentage fines } \\
{[\%]}\end{array}$ & 66.6 & & & & \\
\hline$C_{u}[\mathrm{kPa}]$ & 166 & 174 & 124 & 146 & 123 \\
\hline$C^{\prime}[\mathrm{kPa}]$ & 55 & 120 & 106 & 102 & 79 \\
\hline$\emptyset^{\prime}\left[{ }^{\circ}\right]$ & 22 & 7.3 & 19.2 & 25.5 & 27.0 \\
\hline Liquid limit [\%] & 51.8 & 64.2 & 67.5 & 65.8 & 67.9 \\
\hline Plastic limit [\%] & 29.8 & 32.2 & 33.1 & 34.6 & 32.5 \\
\hline Plastic Index [\%] & 22.1 & 32.0 & 34.4 & 31.2 & 35.3 \\
\hline Free swell [\%] & 41.3 & 41.8 & \multicolumn{4}{|c|}{42.5} & \\
\hline$\rho_{\text {max }}=$ maximum density, $\omega_{\text {opt }}=$ Optimum Water Content, $C_{u}=$ undrained cohesion, $C^{\prime}=$ \\
\hline drained cohesion, $\emptyset^{\prime}=$ drained friction angel, \\
\hline
\end{tabular}

According to USCS (Unified Soil Classification System), the soil is classified as Sand Elastic Silt.

\subsection{Mixture (soil + 5\% HOFA)}

The following statements can be drawn based on Table 1, for the mixture (soil + $5 \%$ HOFA).

- It can be observed a decrease in the value of the drained cohesion of the mixture (soil+5\%HOFA) and an increase in the value of the internal friction angle by the time.

- For the undrained shear parameters $(\mathrm{Cu})$, there is a decrease in the value of undrained cohesion by the time for the mixture (soil+5\%HOFA).

- $\quad$ For the Atterberg limits, they maintain approximately the same values by the time. 


\subsection{Mixture (soil + $10 \%$ HOFA)}

The following statements can be drawn based on Table 1, for the mixture (soil + $10 \%$ HOFA).

- Decrease the value of the drained cohesion and slight increase in the value of the internal friction angle by the time.

- For the undrained shear parameters $(\mathrm{Cu})$, there is a decrease in the value of undrained cohesion by the time.

- $\quad$ For the Atterberg limits, they maintain approximately the same values by the time.

\subsection{Comparison between the effect of two percentages $5 \%$ and $10 \%$}

The experimental results of mixtures (soil+5\%HOFA) and (soil+10\%HOFA) were compared for the both curing periods (7 and 28) days.

\subsubsection{Curing period 7 days}

From the date of Table 1 the following statements can be drawn.

- Decrease in the value of undrained cohesion $(\mathrm{Cu})$ with an increase of the percentage of HOFA.

- Decrease in the value of the drained cohesion and an increase in the value of the internal friction angle with an increase of the percentage of HOFA.

- The liquid and plastic limits were almost the same when increasing the percentage of HOFA, resulting in approximately the same value for the plastic index.

- The free swell also increased slightly with an increase in the percentage of HOFA added to the soil.

\subsubsection{Curing period 28 days}

The authors summarize their statements based on Table 1 .

- The value of undrained cohesion $(\mathrm{Cu})$ is approximately same for the two mixtures.

- Decrease in the value of the drained cohesion and an increase in the value of the internal friction angle with an increase of the percentage of HOFA.

- The liquid and plastic limits were the same when increasing the percentage of HOFA, resulting in the same value for the plastic index. 


\subsection{Comparison between the mixture (soil $+5 \%$ HOFA), mixture (soil+10\%HOFA) and the natural soil}

Since the samples of the mixture (soil +5\% HOFA) and the mixture (soil $+10 \%$ HOFA) were formed depending on the laboratory density and moisture (the same density and moisture for natural soil), while standard proctor was carried out to determine the density and optimum moisture for natural soil, thus the comparison can only for some of the studied parameters:

- Liquid limit $\left(\mathrm{L}_{\mathrm{L}}\right)$.

- $\quad$ Plastic limit $\left(\mathrm{P}_{\mathrm{L}}\right)$.

- $\quad$ Plastic index $\left(\mathrm{P}_{\mathrm{I}}\right)$.

- Free swell.

Fig. 2 shows the change of Liquid Limit, Plastic Limit and Plasticity Index as the HOFA percentage increases, where we observe the followings:

- Increase the liquid limit for the mixture (soil+5\%HOFA) compared with natural soil and it maintains approximately the same value for the mixture (soil+10\%HOFA).

- The plastic limit increases slightly for the mixture (soil+5\%HOFA) compared with natural soil and it maintains approximately the same value for the mixture (soil+10\% HOFA).

- Increase the plasticity index at the percentage $5 \%$ of HOFA mixed with the soil, and this value being almost constant for the percentage $10 \%$.

Fig. 3 shows the change of the free swell value with an increase the percentage of HOFA mixed with the soil. There are not large changes in the value of the free swell by increase of the HOFA. 


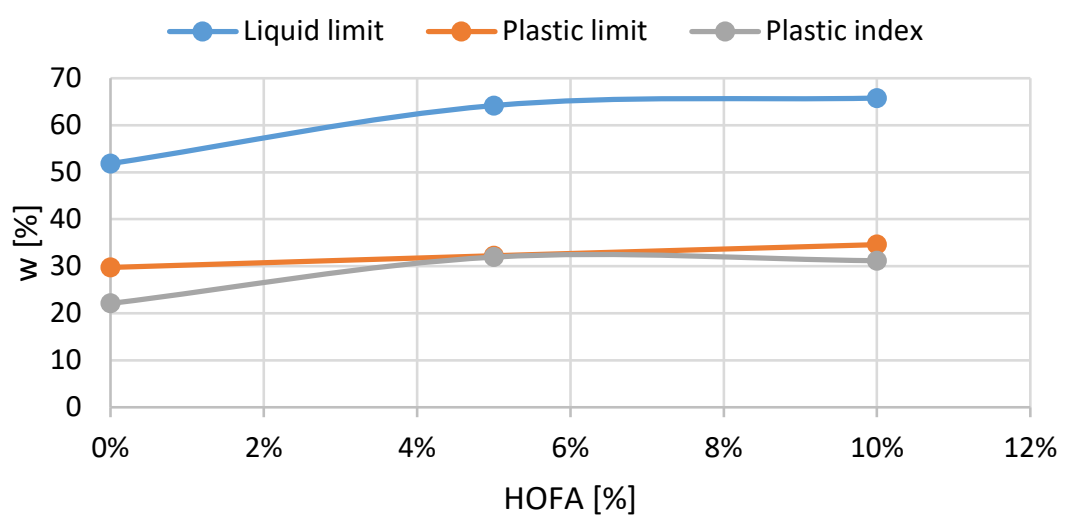

Figure 2. Change of Liquid Limit, Plastic Limit and Plasticity Index with an increase in the percentage of HOFA mixed with the soil

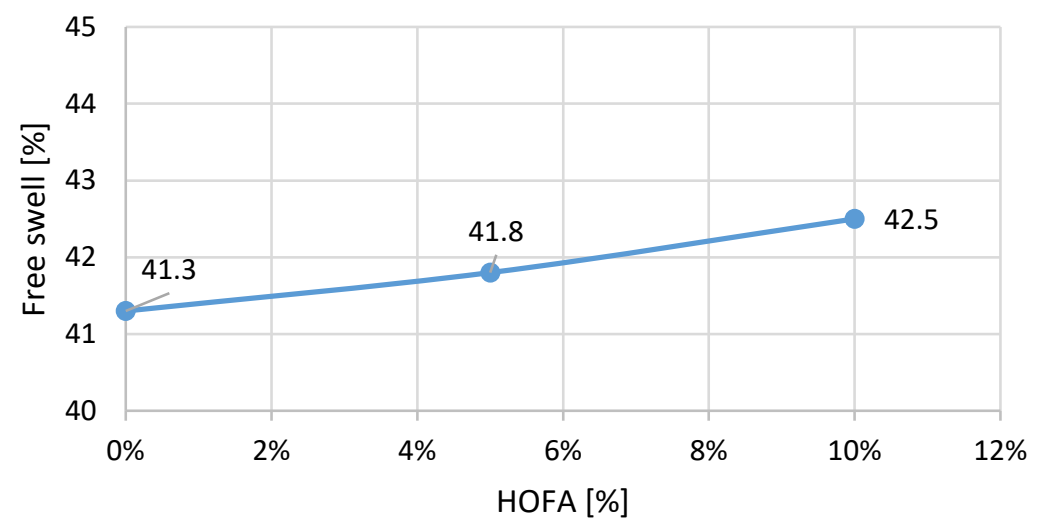

Figure 3. Change of the value of free swell with an increase in the percentage of HOFA mixed with the soil 


\section{Conclusions}

This paper presented an experimental study of the effect of the fly ash that produced at power station of Banias city in Syria which operates by using heavy fuel oil on the geotechnical properties of clay soil. This paper was carried out by mix soil with two different percentages of Heavy Oil Fly Ash (5\% and 10\%) and by using two different curing periods ( 7 and 28 ) days. The main conclusions drawn may be summarized in the following:

- Unlike Fly Ash that caused by burning coal, HOFA chemically inert. Where lack of clear change when comparing the mixture (soil+5\% HOFA) with mixture (soil+10\% HOFA) for Atterberg Limits and Free Swell in addition to absence of clear effect of the curing period on the Atterberg Limits confirm that this type of ash chemically inert and tend to behave as a fill material.

- The increase in the values of the Atterberg Limits that appears at percentage of HOFA equal to $5 \%$ indicates that this type of ash is very voracious for water, and this is due to the very high specific surface area and the high level of carbon as well which had spongy shape and high porosity [1].

- The increase in the value of the friction angle $\left(\varnothing^{\prime}\right)$ with the increase in the percentage of HOFA mixed with the soil can be explained by the fact that the fuel ash granules fill the pores between the soil particles and this naturally leads to an increase in friction when the two percentages are compared (5\%) and (10\%).

- Unlike fly ash produced by burning coal, increase of percentage of HOFA caused decrease mixture cohesion. The decrease in cohesion $\left((\mathrm{Cu})\right.$ and $\left.\left(C^{\prime}\right)\right)$ with an increase in the percentage of HOFA mixed with the soil can be explained by the low cohesion between the heavy oil fuel ash particles.

- The decrease in cohesion $\left((\mathrm{Cu})\right.$ and $\left.\left(\mathrm{C}^{\prime}\right)\right)$ by the time can be explained by the carbon particles absorbs the soil particles moisture.

\section{Acknowledgement}

The authors would like to express thanks to the faculty of civil engineering at Tishreen University, Latakia, Syria and especially for the department of geotechnical engineering. Furthermore, the authors are also grateful to the power station in Banias city for their collaboration with them to carry out this research. 
R. Ousta and A. Tawalo - Acta Technica Jaurinensis, Vol. 14, No. 3, pp. 270-280, 2021

\section{References}

[1] V. K. Lyubov, F. Z. Finker, Reducing the environmental impact of coal-fired thermal power station, AIP Conference Proceedings 2211, 040002 (2020) doi: https://doi.org/10.1063/5.0000816

[2] E. Cokca, Use of Class C Fly Ashes for the Stabilization - of an Expansive Soil, Journal of Geotechnical and Geo-Environmental Engineering 127 (7) (2001) pp. 568-573.

doi: https ://doi.org/10.1061/(ASCE)1090$0241(2001) 127: 7(568)$

[3] N. Pandian, K. Krishna, A. Sridharan. California Bearing Ratio Behavior of Soil/Fly Ash Mixtures, Journal of Testing and Evaluation 29 (2) (2002), pp. 220-226.

doi: https://doi.org/10.1520/JTE12249J

[4] P. R. Phani Kumar, R. S. Sharma, Effect of fly ash on Engineering properties of Expansive Soil, Journal of Geotechnical and Geo-Environmental Engineering 130 (7) (2004) pp. 764-767. doi: https ://doi.org/10.1061/(ASCE)10900241(2004)130:7(764)

[5] M. A. AL-Ghouti, Y. S. AL-Deg et al., Extraction and Separation of Vanadium and Nickel from Fly Ash Produced in Heavy Fuel Power Plants, Chemical Engineering Journal 173 (1) (2011) pp. 191-197. doi: https://doi.org/10.1016/j.cej .2011.07.080

[6] Y. S. AL-Degs, A. Ghrir et al., Characterization and utilization of fly ash of heavy fuel oil generated in power stations, Journal of Fuel Processing Technology 123 (7) (2014) pp. 41-46.

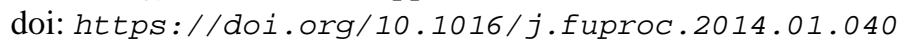

[7] J. Camilleri, M. Anastasi, A. Torpiano, The microstructure and physical properties of heavy oil fuel ash replaced Portland cement for use in flowable fill concrete and the production of concrete masonry units, Journal of Construction and Building Materials 38 (1) (2014) pp. 970-979. doi: https ://doi .org/10.1016/j . conbuildmat . 2012 . 09.054

[8] M. Shmlls, D. Bozsaky, T. Horváth, Literature review on steel fibre, silica fume and fly ash: improving methods for recycled and multiple recycled 
aggregate concretes, Acta Technica Jaurinensis 14 (1) (2021) pp. 60-79. doi: https://doi.org/10.14513/actatechjaur. 00570

[9] B. D. Nath, M. K. A. Molla, G. Sarkar, Study on Strength Behavior of Organic Soil Stabilized with Fly Ash, International Scholarly Research Notices 2017 (2017), Article ID 5786541, pp. 1-6. doi: https ://doi.org/10.1155/2017/5786541

[10] S. Mahvash, S. López-Querol, A. Bahadori-Jahromia, Effect of class F fly ash on fine sand compaction through soil stabilization, Heliyon 3 (3) (2017) pp. $1-27$.

doi: https://doi.org/10.1016/j.heliyon. 2017.e00274 